\title{
Enterprise's performance evaluation on the basis of value added
}

\author{
Doina Păcurari, Vasile Alecsandri University of Bacău \\ Mircea Muntean, Vasile Alecsandri University of Bacău
}

\begin{abstract}
:
Important indicator, used in performance analysis, value added expresses enterprise's contribution to national gross domestic product. The value added through economic activity developed by enterprise should assure the remuneration of all its life participants: employees, investors, state and enterprise itself. Information referring to enterprise capacity of generating value added should be based on decisions concerning future enterprise decisions. The present article presents, by means of a case study, value added calculation (by subtractive and additive method) and their analysis.
\end{abstract}

\section{Key words:}

added value, performance, subtractive method, additive method, production factors, remuneration

One of the main indicators used in European countries for enterprise's performance appreciation is value added. This offers a wide perspective on the enterprise's capacity of value creation, taking into consideration not only the investors interests but the ones of the other direct or indirect participants to economic activity as well.

The value added expresses the increase on value obtained in the frame of current activity, resulted from use of resources that enterprise may dispose, over the value of goods and services emanated from third parties.

The production of the exercise constitutes the indicator that is placed at the basis of value added determination. This aspect is due to the fact that the production is the measure of activity developed by enterprise during the financial exercise, activity for which external supplies, under the form of intermediary consumption, were consumed. The difference remaining after these consumption deductions represents the value added produced through own production factors contribution.

The value added is found between purchasers (upstream market) and sales (downstream market), being a measure for action means suitable to enterprise and characterising therefore its performance.

The relevance of value added surpasses the one of turnover, the latter being incapable of measuring the economic enterprise's power. There may be enterprises that register the same turnover but have different activity objectives and the value added that it realised is also a different one. Unlike the turnover, that also includes the value of purchases of raw materials, materials, goods and services (that are found in the turnover of providing firms), the value added comprises only the equivalent of the considered enterprise's activity.

By its content, the value added is the microeconomic equivalent of gross domestic product. Also, gross domestic product represents the sum of enterprise's values added registered on national level.

The indicator expresses the enterprise's contribution to total goods and services production, on branch or national level, allowing the appreciation of methods used in productive process as well as in production's structure and integration degree. 
Information given by analysis and diagnostic of value added has to stay, among others, on the basis of the managerial decisions concerning enterprise's future development. The future performance planning cannot be realised without taking into consideration the enterprise's capacity of generating added value.

The value added may be determined through two methods:

$>$ subtractive method (synthetic), according to which goods and services consumption coming from third parties are subtracted from the realised production;

$>$ additive method (analytical), which supposes a reversed process, pointing out the repartition elements of value added, where actually the production costs that has to be remunerated are involved.

\section{The analysis of value added calculated by subtractive method (synthetic)}

According to subtractive method, value added (VA) is calculated as difference between the exercise production $(\mathrm{Pe})$, to which commercial margin $(\mathrm{Mc})$ is added (whether the enterprise also has commercial activity) and intermediate consumption of goods and services $(\mathrm{Ci})$ coming from the third parties:

$$
V A=P e+M c-C i t
$$

Commercial margin, as difference between sales of goods and their purchase cost represents the supplement value brought by commercial activity, as sold value added. By reporting the value added to turnover the degree of economic integration of production can be determined, on vertical. The higher is the enterprise economic integration, the lower are the external contribution dependence and afferent risk degree.

In order to illustrate, we present in follow up the value added calculation through subtractive method. Example used is that of a retail company, from construction materials domain. The analysis was realised for 2004-2008 period, on the basis of data published in yearly financial statements.

Table no.1. Value added calculated by subtractive method

-thousands lei-

\begin{tabular}{|r|l|r|r|r|r|r|}
\hline \multirow{2}{*}{ No } & \multicolumn{5}{|c|}{ Specification } & \multicolumn{5}{c|}{ Year } \\
\cline { 3 - 6 } & & 2004 & 2005 & 2006 & 2007 & \multicolumn{1}{c|}{2008} \\
\hline 1 & Commercial margin (Mc) & 16.892 & 25.197 & 36.315 & 58.310 & 93.058 \\
\hline 2 & Exercise production (Pe) & 520 & 561 & 1.614 & 4.991 & 5.412 \\
\hline 3 & $\begin{array}{l}\text { Commercial margin + Exercise } \\
\text { production (rd.1+2) }\end{array}$ & 17.412 & 25.758 & 37.929 & 63.301 & 98.470 \\
\hline 4 & Total material expenses * & 1.712 & 2.953 & 5.725 & 9.993 & 12.021 \\
\hline 5 & $\begin{array}{l}\text { Goods and services from the third } \\
\text { parties }\end{array}$ & 2.681 & 3.700 & 7.706 & 14.044 & 12.385 \\
\hline 6 & $\begin{array}{l}\text { Intermediate consumption (Ci) } \\
\text { (rd.4+5) }\end{array}$ & 4.393 & 6.653 & 13.431 & 24.037 & 24.406 \\
\hline 7 & Value added (VA) (rd.3-6) & 13.019 & 19.105 & 24.498 & 39.264 & 74.064 \\
\hline 8 & Index increase of Mc (\%) & 100 & 149 & 215 & 345 & 551 \\
\hline 9 & Index increase of Pe (\%) & 100 & 108 & 310 & 960 & 1040 \\
\hline 10 & Index increase of Mc+Pe (\%) & 100 & 148 & 218 & 364 & 566 \\
\hline 11 & Index increase of Ci (\%) & 100 & 151 & 306 & 547 & 556 \\
\hline 12 & Index increase of VA (\%) & 100 & 147 & 188 & 302 & 569 \\
\hline 13 & Turnover (T) & 80.132 & 121.012 & 174.780 & 254.087 & 395.491 \\
\hline 14 & Rate of value added(VA/T) (\%) & 16 & 16 & 14 & 15 & 19 \\
\hline
\end{tabular}


* includes row materials and consumables, other material expenses and external charges (on energy and water)

According to above presented data, the value added registered an increasing tendency, more emphasized in the latter part of the period. Except the year 2008, the growth rate of value added was inferior to the growth of intermediate consumption. The value added rate maintained in 2004-2007 period around $15 \%$, in 2008 registered an increase of $4 \%$, reaching therefore a level of $19 \%$. This evolution indicates a conservation of the vertical integration degree, respectively of enterprise's dependence on external material resources acquisitions.

\section{The analysis of value added calculated by additive method (analytic)}

The additive method is a repartition method that supposes the summing of structural elements of new-created value, namely: staff expenses (wages and social protection expenses), taxes due the state (excepting the value added tax), financial expenses, depreciation of fixed assets and respectively the net value added after depreciation deduction.

According to this method, value added may be calculated starting either from the net result of financial exercise or from the operating result, as following:

a) On the basis of net result:

$$
V A=R n-I e x+E e x-I f+E f-\text { Other Io }+ \text { Other Eo }-I o s+A j+\text { Tax }+E s
$$

where:

VA - value added

$\mathrm{Rn}$ - net result

Iex / Eex - extraordinary revenues / extraordinary expenses

If / Ef - financial revenues / financial expenses

Io / Eo - operating revenues / operating expenses

Ios - revenues from operating subsidies

$\mathrm{Aj}$ - adjustments concerning provisions and value adjustments on assets

Tax -other taxes, duties and similar expenses

Es - staff expenses

b) On the basis of operating result:

$$
V A=R o-\text { Other Io }+ \text { Other Eo }- \text { Ios }+A j+\text { Tax }+E s
$$

This calculation pattern highlight the investment consumptions role (represented by expenses with depreciation and adjustments for impairment of assets), next to other production factors, on the gross value added creation. By excluding the depreciation and adjustments concerning the fixed assets $\left(\mathrm{A}_{\text {jai }}\right)$ the net value added is obtained:

$$
\text { Net value added }=\text { Gross value added }-A_{\text {jai }}
$$

In interpreting the net value added there should be taken into consideration the methods used by enterprise in what the fixed assets evaluation and depreciation is concerned.

The determination of the value added through additive method allows analysis such as growth factors, value added structure according to the contributors to capital as well as value added distribution to the remuneration the production factors - labor and capital, the only ones who contribute to realisation of new created value.

For the analysed firm, the value added calculated starting from the operating result is presented as follows:

Table no.2. Value added calculated by additive method 


\begin{tabular}{|c|l|r|r|r|r|r|}
\hline \multirow{2}{*}{ No } & \multicolumn{1}{|c|}{ Specification } & \multicolumn{5}{c|}{ Year } \\
\cline { 3 - 7 } & & 2004 & 2005 & 2006 & 2007 & 2008 \\
\hline 1 & Operating result & 10.757 & 13.476 & 13.930 & 27.638 & 52.222 \\
\hline 2 & Other operating revenues & 0 & 803 & 1.039 & 3.313 & 15.129 \\
\hline 3 & Other operating expenses * & 0 & -613 & -808 & 3.063 & 16.007 \\
\hline 4 & $\begin{array}{l}\text { Revenues from operating } \\
\text { subsidies }\end{array}$ & 0 & 0 & 0 & 0 & 0 \\
\hline 5 & Adjustments on provision & 0 & 0 & 0 & 0 & 0 \\
\hline 6 & $\begin{array}{l}\text { Adjustments for impairment of } \\
\text { assets }\end{array}$ & 669 & 3.669 & 6.561 & 4.417 & 7.057 \\
\hline 7 & Value adjustments on assets & 0 & 21 & 168 & 21 & 67 \\
\hline 8 & $\begin{array}{l}\text { Other taxes, duties and similar } \\
\text { expenses }\end{array}$ & 345 & 356 & 573 & 617 & 975 \\
\hline 9 & Staff expenses & 1.248 & 2.999 & 5.113 & 6.821 & 12.864 \\
\hline 10 & $\begin{array}{l}\text { Gross value added (rd.1-2+3- } \\
\text { 4+5+6+7+8+9) }\end{array}$ & 13.019 & 19.105 & 24.498 & 39.264 & 74.063 \\
\hline 11 & Net value added (rd.10-6) & 12.350 & 15.436 & 17.937 & 34.847 & 67.006 \\
\hline
\end{tabular}

* Only expenses with compensations, donations and disposal of assets are retained from heading "Other operating expenses" in the Income Statement.

Structural analysis of the value added points out the participation of the repartition elements on the creation of value added and reflects the production factors remuneration according to each contribution:
a) labor remuneration $=\frac{\text { Staff expenses }}{\text { Value added }}$
b) state remuneration $=\frac{\text { Taxes and charges }}{\text { Value added }}$
c) creditors remuneration $=\frac{\text { Financial expenses }}{\text { Value added }}$
d) investments remuneration $=\frac{\text { Amortizations and depreciation adjustments }}{\text { Value added }}$
e) enterprise remuneration $=\frac{\text { Net profit }}{\text { Value added }}$

The remuneration of the production factors on the account of value added highlights the fact that every factor incorporates two different parts: one corresponds to an added cost for enterprise and other corresponds to a sampling of result.

The added cost is the cost of enterprise activity, added to goods and services purchased from outside, while the sampling of result are components of net result that are distributed to production factors under the form of dividends, profit tax, selffinancing.

Analysed as a sum of added costs and shares of results, the value added offers an image on the evolution of these costs, from where useful information for accounting result. Schematically, this summing can be represented as follows:

\begin{tabular}{|lllll|}
\hline Added value & $=$ & Added costs & + & Shares from result \\
\hline I. Labor & $=$ & Staff expenses & + & Employee participation in profits \\
\hline
\end{tabular}




\begin{tabular}{|llll|}
\hline II. Capitals & $=$ Financial expenses & + Shareholders dividends \\
III. State & $=$ Taxes and charges & + Profit tax \\
IV.Enterprise & $=$ Amortisements & + & Self financing \\
\hline
\end{tabular}

The value added structuring according to remuneration of participants in the enterprise activity supposes the knowing of the profit distribution modality, aspect found in explanatory notes of annual financial statements.

Table no. 3. Structure of value added on participants in the business of the company

\begin{tabular}{|c|c|c|c|c|c|c|}
\hline \multirow{3}{*}{ No } & \multirow{3}{*}{ Specification } & \multicolumn{5}{|c|}{-thousands lei- } \\
\hline & & \multicolumn{5}{|c|}{ Year } \\
\hline & & 2004 & 2005 & 2006 & 2007 & 2008 \\
\hline 1 & Labor remuneration (rd.1a+1b) & 924 & 2.222 & 7.859 & 12.123 & 25.865 \\
\hline $1 \mathrm{a}$ & -staff expenses & 924 & 2.222 & 3.859 & 5.123 & 9.865 \\
\hline $1 \mathrm{~b}$ & $\begin{array}{l}\text {-employee participation in } \\
\text { profits }\end{array}$ & 0 & 0 & 4.000 & 7.000 & 16.000 \\
\hline 2 & $\begin{array}{l}\text { Taxes and charges due the state } \\
(\mathrm{rd} .2 \mathrm{a}+2 \mathrm{~b}+2 \mathrm{c})\end{array}$ & 2.945 & 3.896 & 4.923 & 6.246 & 11.589 \\
\hline $2 \mathrm{a}$ & -social insurance and protection & 324 & 776 & 1.254 & 1.697 & 2.998 \\
\hline $2 \mathrm{~b}$ & $\begin{array}{l}\text {-other taxes, duties and similar } \\
\text { expenses }\end{array}$ & 345 & 357 & 573 & 617 & 975 \\
\hline $2 \mathrm{c}$ & -profit tax & 2.276 & 2.763 & 3.095 & 3.932 & 7.615 \\
\hline 3 & $\begin{array}{l}\text { Creditors } \\
\text { (rd.3a) }\end{array}$ & 111 & 241 & 602 & 1.422 & 2.296 \\
\hline $3 \mathrm{a}$ & -interest expenses & 111 & 241 & 602 & 1.422 & 2.296 \\
\hline 4 & $\begin{array}{l}\text { Shareholders } \\
\text { (rd.4a) }\end{array}$ & 0 & 8.283 & 5.955 & 10.906 & 15.819 \\
\hline $4 a$ & -dividends & 0 & 8.283 & 5.955 & 10.906 & 15.819 \\
\hline 5 & $\begin{array}{l}\text { Self-financing enterprise } \\
(\mathrm{rd} .5 \mathrm{a}+5 \mathrm{~b})\end{array}$ & 8.749 & 4.271 & 8.128 & 12.510 & 27.600 \\
\hline $5 a$ & $\begin{array}{l}\text {-adjustments for impairment of } \\
\text { assets and provisions }\end{array}$ & 669 & 3.690 & 6.729 & 4.439 & 7.125 \\
\hline $5 b$ & -profit carried forward & 8.081 & 581 & 1.400 & 8.071 & 20.476 \\
\hline 6 & Correction elements* & 290 & 190 & -2.970 & -3.945 & -9.106 \\
\hline 7 & Value added (rd.1+2+3+4+5+6) & 13.019 & 19.105 & 24.498 & 39.264 & 74.063 \\
\hline 8 & $\begin{array}{l}\text { Labor remuneration }(\%) \\
(\mathrm{rd} .1 / \mathrm{rd} .7)\end{array}$ & 7 & 12 & 32 & 31 & 35 \\
\hline 9 & $\begin{array}{l}\text { State remuneration }(\%) \\
\text { (rd.2/rd.7) }\end{array}$ & 23 & 20 & 20 & 16 & 16 \\
\hline 10 & $\begin{array}{l}\text { Creditors remuneration }(\%) \\
(\mathrm{rd} .3 / \mathrm{rd} .7)\end{array}$ & 1 & 1 & 2 & 4 & 3 \\
\hline 11 & $\begin{array}{l}\text { Shareholders remuneration }(\%) \\
(\mathrm{rd} .4 / \mathrm{rd} .7)\end{array}$ & 0 & 43 & 24 & 28 & 21 \\
\hline 12 & $\begin{array}{l}\text { Enterprise remuneration }(\%) \\
(\mathrm{rd} .5+6 / \mathrm{rd} .7)\end{array}$ & 69 & 24 & 22 & 21 & 25 \\
\hline
\end{tabular}

* The influence of other elements besides those contained in previous sections

According to data from table no. 3 , there is a reduction in the proportion (from $23 \%$ in 2004 to $16 \%$ for 2007 and 2008) that taxes and charges due the state has in value added, because reducing taxation. In the same time, the proportion held by staff 
remuneration increased from $7 \%$ in 2004 to $35 \%$ in 2008 . The financial creditors' remuneration was pretty low during the entire period, having a proportion between $1 \%$ and $4 \%$. If in 2004 the entire net profit was retained as financing source for the enterprise, starting with 2005 the net profit was distributed both for enterprise and shareholders remuneration (dividends) and starting with 2006 also for employees remuneration (employee participation in profits). The enterprise remuneration maintained in 2005-2008 period between $21 \%-25 \%$ which assured a gradual increase of the self-financing capacity and the own equity.

A better assessment of value added evolution can be made if the inflation effect is also taken into consideration. For this purpose, the values of analyzed indicator are recalculated, corrected with the index increase of prices, according to the following table:

Table no.4. Value added expressed in comparable prices

\begin{tabular}{|c|l|r|r|r|r|r|}
\hline No & \multicolumn{1}{|c|}{ Specification } & \multicolumn{5}{|c|}{ Year } \\
\cline { 3 - 7 } & & 2004 & \multicolumn{1}{|c|}{-thousands lei- } & \multicolumn{1}{|c|}{2006} & 2007 & 2008 \\
\hline 1 & Value added (VA) & 13.019 & 19.105 & 24.498 & 39.264 & 74.063 \\
\hline 2 & $\begin{array}{l}\text { Index increase of prices } \\
(\%) \text { (IP) }\end{array}$ & 100 & 111,9 & 122,0 & 129,9 & 136,2 \\
\hline 3 & $\begin{array}{l}\text { VA in comparable prices } \\
(\text { VAcp = VA/IP) }\end{array}$ & 13.019 & 17.074 & 20.081 & 30.226 & 54.378 \\
\hline 4 & $\begin{array}{l}\text { Index increase of VAcp } \\
(\%)\end{array}$ & 100 & 131 & 154 & 232 & 418 \\
\hline 5 & Variation of VAcp (\%) & 0 & 31 & 54 & 132 & 318 \\
\hline
\end{tabular}

The value added trend between 2004 and 2008 is presented graphically as:

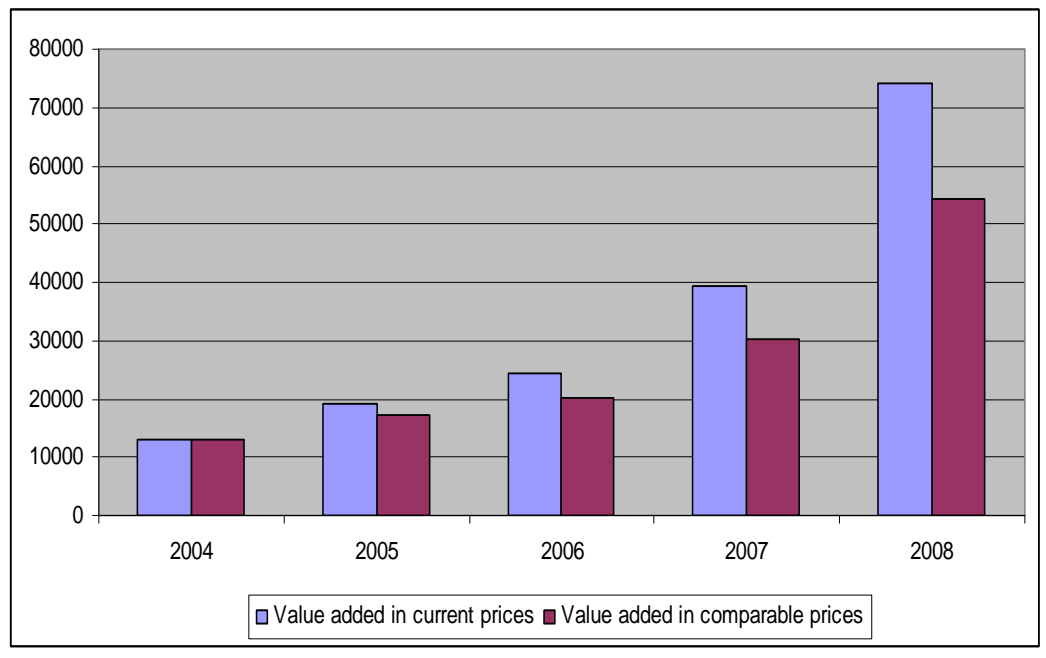

As a general assessment, we may state that during the period under review added value, both the one expressed in current prices and the one expressed in comparable prices, followed a growth tendency, more emphasized towards the end of the period. This evolution expresses the development of the creative purpose of enterprise, more precisely the increasing of value it adds to goods purchased from the third parties and commercialized. 


\section{Bibliography}

1. Muntean, M.(2006), Analiza echilibrului economico-financiar al întreprinderilor comerciale, Ed.EduSoft, Bacău

2. Păcurari, D. (2009), Diagnostic şi strategie în societăţile comerciale pe baza informaţiilor de sinteză ale contabilitătii, Ed. Tehnopress, Iaşi

3. Păvăloaia, W., Paraschivescu, M.D., Olaru, G.D., Radu, F. (2006), Analiza financiară: studii de caz, Ed.Tehnopress, Iaşi

4. Petrescu, S. (2008), Analiză şi diagnostic financiar-contabil: ghid teoretico-aplicativ, ed.a IIa rev., Ed. CECCAR, Bucureşti 